\title{
History of spinal cord localization
}

\author{
Sait Naderi, M.D., UĞUr Türe, M.D, and T. Glenn Pait, M.D. \\ Departments of Neurosurgery, Dokuz Eylül University School of Medicine, Izmir, Turkey; \\ Ondokuz Mayls University School of Medicine, Samsun, Turkey; and Departments of Neurosurgery \\ and Orthopedic Surgery, The Jackson T. Stephens Spine and Neurosciences Institute of the University \\ of Arkansas for Medical Sciences, Little Rock, Arkansas
}

\begin{abstract}
The first reference to spinal cord injury is recorded in the Edwin Smith papyrus. Little was known of the function of the cord before Galen's experiments conducted in the second century AD. Galen described the protective coverings of the spinal cord: the bone, posterior longitudinal ligament, dura mater, and pia mater. He gave a detailed account of the gross anatomy of the spinal cord. During the medieval period (AD 700-1500) almost nothing of note was added to Galen's account of spinal cord structure. The first significant work on the spinal cord was that of Blasius in 1666. He was the first to differentiate the gray and white matter of the cord and demonstrated for the first time the origin of the anterior and posterior spinal nerve roots. The elucidation of the various tracts in the spinal cord actually began with demonstrations of pyramidal decussation by Mistichelli (1709) and Pourfoir du Petit (1710). Huber (1739) recorded the first detailed account of spinal roots and the denticulate ligaments. In 1809, Rolando described the substantia gelatinosa. The microtome, invented in 1824 by Stilling, proved to be one of the fundamental tools for the study of spinal cord anatomy. Stilling's technique involved slicing frozen or alcohol-hardened spinal cord into very thin sections and examining them unstained by using the naked eye or a microscope. With improvements in histological and experimental techniques, modern studies of spinal cord anatomy and function were initiated by Brown-Séquard. In 1846, he gave the first demonstration of the decussation of the sensory tracts. The location and direction of fiber tracts were uncovered by the experimental studies of Burdach (1826), Türck (1849), Clarke (1851), Lissauer (1855), Goll (1860), Flechsig (1876), and Gowers (1880). Bastian (1890) demonstrated that in complete transverse lesions of the spinal cord, reflexes below the level of the lesion are lost and muscle tone is abolished. Flatau (1894) observed the laminar nature of spinal pathways.

The 20th century ushered in a new era in the evaluation of spinal cord function and localization; however, the total understanding of this remarkable organ remains elusive. Perhaps the next century will provide the answers to today's questions about spinal cord localization.
\end{abstract}

\section{KEY WORDS - history of neurosurgery - localization - spinal cord}

The history of the detailed anatomy of the spinal cord is relatively short compared with that of other parts of the nervous system. This is because few advancements in the knowledge of its finer structures could be made before appropriate technical facilities became available in the middle of the 19th century. In addition, knowledge acquired during the ancient and medieval periods had little impact on later studies. In this report, however, we will address the collected data of all periods.

\section{THE ANCIENT PERIOD}

Knowledge of spinal cord anatomy during the ancient period evolved from experiences gained from observing spinal traumas and theories regarding the spirits (pneuma).

\section{Edwin Smith Papyrus (2600 BC)}

The first examples of experience-based information were reported in the Edwin Smith papyrus. ${ }^{2,11,12}$ It is believed that this document was written by Imhotep (Fig. 1 upper). Six of 48 cases reported in this papyrus are relat- ed to spinal injury. This 4600-year-old document addresses vertebral subluxation and dislocation, and quadriplegia and paraplegia in patients with upper and lower cervical spine injuries. ${ }^{2}$

It has been estimated that the ancient Assyrians had no idea about the functions of the spinal cord. Nevertheless, a relief from the Palace of Asshurbanipal (ca 650 BC) depicts a dying lioness, which has been injured by arrows, trying to crawl forward while dragging her paralyzed limbs (Fig. 1 lower). This scene indicates that there was some degree of appreciation of the consequences of a spinal cord injury.

\section{Hippocrates (460-375 BC)}

Hippocrates (Fig. 2) believed that the spinal cord was connected to the kidneys and to the genital organs of males through the veins. ${ }^{5-7,22}$ This is in line with relevant beliefs expounded in some other ancient treatises ${ }^{8,19}$ that sperm is produced within the spinal cord.

Hippocrates gave very precise information about the clinical consequences of spinal cord injury. Among his 

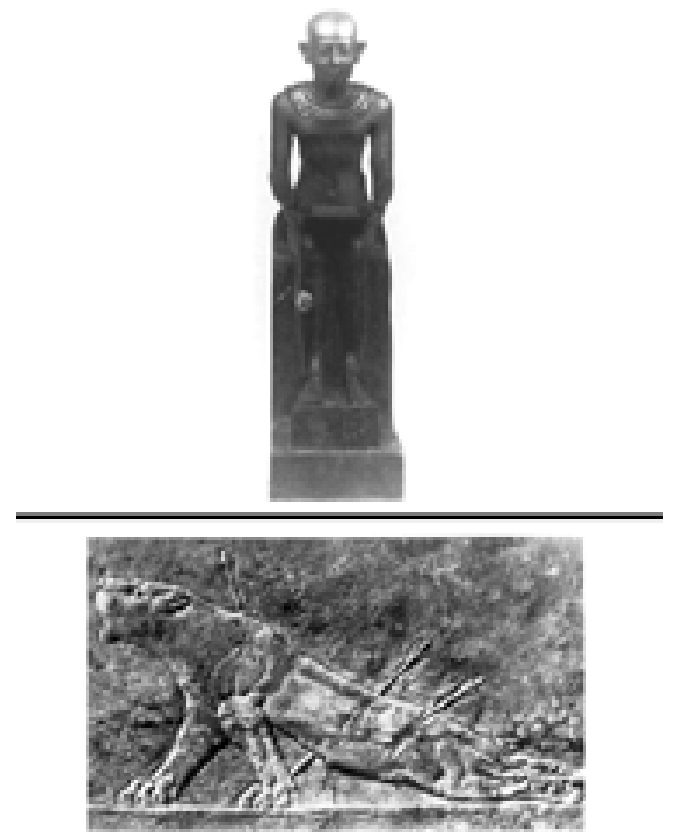

Fig. 1. Upper: Photograph showing a statue of Imhotep. From the Egyptian Museum in Cairo, Egypt. Lower: The Dying Lioness, detail of a relief from the Palace of Asshurbanipal, 650 BC. The spinal cord of the lioness has been injured by arrows; however, she tries to crawl forward while dragging her paralyzed limbs. From the British Museum, London, UK.

most important contributions were his two different "benchs"- the Hippocratic ladder and the Hippocratic board-which were used for reduction of fractures and fracture-dislocations. ${ }^{15}$ Similar traction devices were used before and after Hippocrates. ${ }^{13}$ It is well known that Srimad Bhagwat Mahapuranam, an ancient Indian epic estimated to have been written between 3500 and 1800 $\mathrm{BC}$, contains a report on the use of such a traction bench by Lord Krishna. ${ }^{11,20}$ Other benches were reported also by Paulus of Aegina, Avicenna, Abulcasis, and Sabuncuoglu.

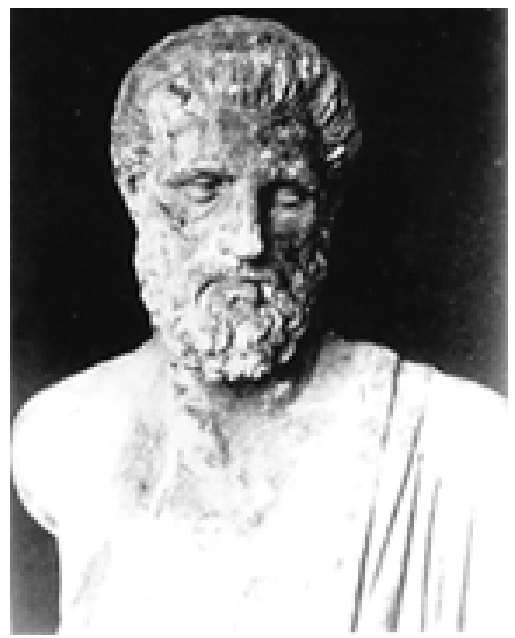

Fig. 2. One of the earliest known statues of Hippocrates.

\section{Herophilus (325-260 BC)}

Herophilus described the caudal prolongation of the rhombencephalon, which he termed the "spinal cord" and believed was the source from which nerves arose. According to Herophilus (Fig. 3 upper), "the neura that make voluntary motion possible have their origin in the cerebrum (enkephalos) and spinal marrow" (Rufus Ephesius, De anatomica partium hominis 71-5). Despite several dissections, Herophilus never mentioned the spinal cord in detail. .0,24 $^{2}$

\section{Aretaeus of Cappadocia (AD 81-138)}

Aretaeus (Fig. 3 lower) was born in Cappadocia in Asia Minor and was educated in Alexandria. He stated that the channels carrying the "motor spirits" must cross, forming the letter X. ${ }^{12}$

\section{Galen (AD 130-200)}

Little was known of the function of the spinal cord before experiments performed by Galen. ${ }^{10} \mathrm{He}$ described the protective coverings of the spinal cord: the bony elements, the posterior longitudinal ligament, and the dura and pia mater. ${ }^{16}$ Galen noted that a bundle of filaments emerged on each side of the spinal cord from the vertebral canal through the round lateral foramina. He believed these fibers conveyed spirits from the brain to the muscles. It is interesting that Galen modified a hypothesis formed by Aristotle (384-322 BC) regarding what the latter called "pneuma," which is possibly analogous to an element derived from the stars, that was inhaled in breathing. This substance was drawn into the heart, where it became "vital pneuma" and was distributed through blood vessels to initiate the activities of organs. Galen suggested that when vital pneuma enters the brain, it is converted into psychic pneuma. From the brain it passes down the cranial nerves

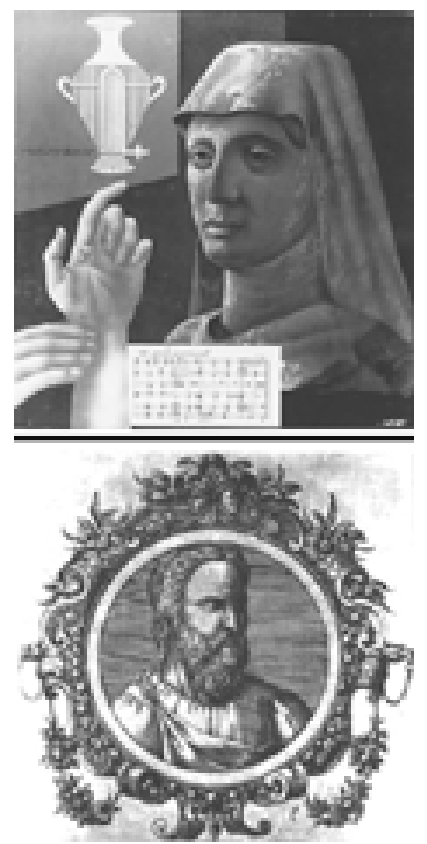

Fig. 3. Upper: Statue of Herophilus. Lower: Drawing of Aretaeus. 
and spinal cord and out of the spinal nerves to activate muscle. It is clear that Galen conceived of psychic pneuma as a fluid that flowed within hollow tubes in the nerves, somewhat akin to the modern concept of an action potential. ${ }^{1}$

Galen named deformities of the spine such as lordosis, kyphosis, and scoliosis. He confirmed the observations of Imhotep and Hippocrates regarding the neurological sequences of cervical trauma. He observed that injuries to the cervical spinal cord caused a certain level of loss of sensation and motor function, whereas injuries in lower areas caused a different level of paralysis. He gave a detailed account of the dissection of the spinal cord. ${ }^{16}$ During the Medieval Era nothing of note was added to Galen's account of spinal cord structure and functions; even the early Renaissance anatomists failed to contribute new or original observations.

\section{THE MEDIEVAL PERIOD}

Oribasius (AD 325-403)

Based on Galen's experiments, Oribasius provided clearcut descriptions of the effects of lesions at different levels of the spinal cord. He added a bar to the Hippocratic bench and used it for reduction of both traumatic spinal injuries and deformities. ${ }^{20}$

\section{Paulus of Aegina (AD 625-690)}

Paulus collected the most basic knowledge accumulated during the 1000 years preceding him into a sevenvolume encyclopedia. The idea of using splints after reduction of spine fractures is ascribed to Paulus, who also seems to have performed the first laminectomies for patients with spinal injuries in which the posterior elements had been fractured and pushed into the spinal cord. Paulus of Aegina also used the Hippocratic bench to treat spinal disorders. ${ }^{4,12,17}$

\section{Avicenna (AD 980-1037)}

As one of the authors has previously stated elsewhere, ${ }^{18}$ Avicenna (Fig. 4) believed that the spine functions as a canal for the spinal cord.

If all the nerves exited directly from the brain, the brain would be bigger. For example, nerves innervating the hands

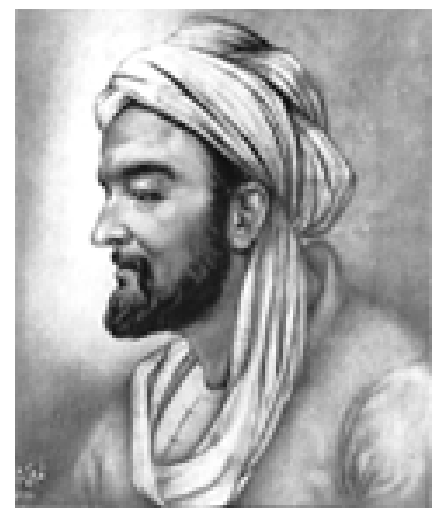

Fig. 4. Portrait of Avicenna. and feet would travel a longer distance and, thus, would be more prone to injury; they would also become less able to innervate the big muscles of the thigh and the calf. Therefore, God created the spinal cord below the brain. The spinal cord is like a channel coming out of a fountain in the way that nerves emerge from both sides and go down, thus putting the organs closer to the brain. That is why God placed the spinal cord into a hard bony channel called the spine to protect it from injury. ${ }^{18}$

\section{THE RENAISSANCE AND MODERN PERIODS}

\section{Andreas Vesalius (1514-1564)}

Although Vesalius (Fig. 5) frequently relied on Galen's earlier work for ideas regarding the functions of the body, he recorded his own knowledge of its structure. The fourth book of the De Humani Corporis Fabrica (1543) contains his overall view of the anatomy of the nervous system. The two sets of spinal cord roots are not delineated, however, and the description of the spinal cord is poor. ${ }^{12}$

\section{Gerard Blasius (1625-1692)}

The first significant work on the spinal cord was performed by the Dutch anatomist Blasius. In his Anatome Medullae Spinalis Nervorum (1666), Blasius was the first to provide a demonstration of the origin of the anterior and posterior spinal nerve roots and a differentiation between the gray and white matter of the spinal cord. He was the first to illustrate clearly the $\mathrm{H}$ shape of gray matter in a cross-section of the spinal cord. ${ }^{17}$

\section{Domenico Mistichelli (1675-1715)}

Several centuries after Aretaeus completed his anatomical work regarding the crossing of the motor spirits, the various tracts in the spinal cord began to be elucidated by demonstrations of pyramidal decussation undertaken by Mistichelli, a professor of medicine at Pisa in 1709.3,4,17

\section{Francois Pourfour du Petit (1664-1741)}

Francois Pourfour du Petit, a French neurologist, described the decussation of the pyramids more accurately and in greater detail than his predecessors. In 1710 he gave a brief account of the internal structure of the cord, one of the first descriptions having significant merit. ${ }^{3,12,17}$

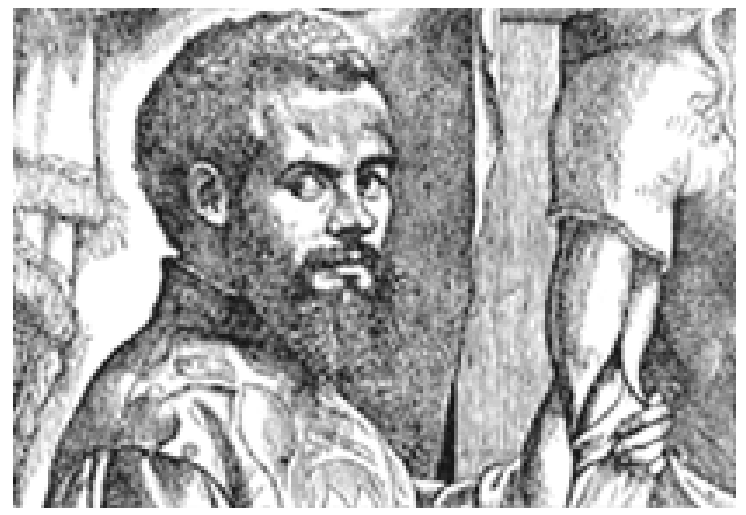

Fig. 5. Portion of an illustration showing Vesalius. 


\section{Johann Jacob Huber (1707-1778)}

The first detailed and accurate description of the spinal cord appears to have been made by the Swiss anatomist Huber. His anatomical work mainly focused on the spinal cord and nerves, and he is credited with providing the first detailed account of spinal roots and denticulate ligaments in 1739.3 .17

\section{Felix Vicq d'Azyr (1748-1794)}

Huber suggested that the spinal cord be divided into columns and the French anatomist Vicq d'Azyr expanded this idea in 1786. The partition into a right and a left half was important from the clinical viewpoint because it was thought to explain some forms of hemiplegia. Vicq d'Azyr elaborated on the arrangement of the fiber bundles of the spinal cord and their division into a posterior and two lateral segments (columns) and a white anterior commissure. $3,4,12,17$

\section{Luigi Rolando (1773-1831)}

The Italian anatomist Rolando described the substantia gelatinosa of the spinal cord in 1809. 3,4,17

\section{Charles Bell (1774-1842)}

Charles Bell, the famous English surgeon and experimental physiologist, revealed in 1811 that the anterior roots of the spinal nerves are dedicated to the function of conveying motor impulses from the brain to other parts of the body, whereas the posterior roots only convey sensory impulses to the brain from outside that organ. Previously, it had been supposed that all nerves have a similar function. ${ }^{3,4,12,14,17}$

\section{Karl Fredrich Burdach (1776-1847)}

In 1826 the German physiologist Burdach described the fasciculus cuneatus, which is also known as the Burdach tract. $3,4,17$

\section{Benedict Stilling (1810-1879)}

A German anatomist and surgeon, Stilling invented the microtome, which proved to be a fundamental tool for the study of spinal cord anatomy. He developed a technique for examining the spinal cord, which eventually revealed a remarkable amount of detail of its internal structure. This involved slicing frozen or alcohol-hardened specimens of spinal cord, as one would slice a cucumber, into a series of very thin sections and examining them unstained by using the naked eye or a microscope, usually one with a low power. Stilling was thus the first scientist to use serial sections. His investigations revealed to him the importance of the gray matter. In 1846 he stated that the gray matter was not only the anatomical, but also the actual physiological nucleus of the spinal cord and devoted a long description to its structure. Using his technique, Stilling observed the contrast between gray and white matter, the longitudinal course of some tracts, and the transverse course of others in detail (Fig. 6). Stilling also noted that fibers radiated from the horns of the central gray matter to the anterior white matter., ${ }^{3,12,17}$

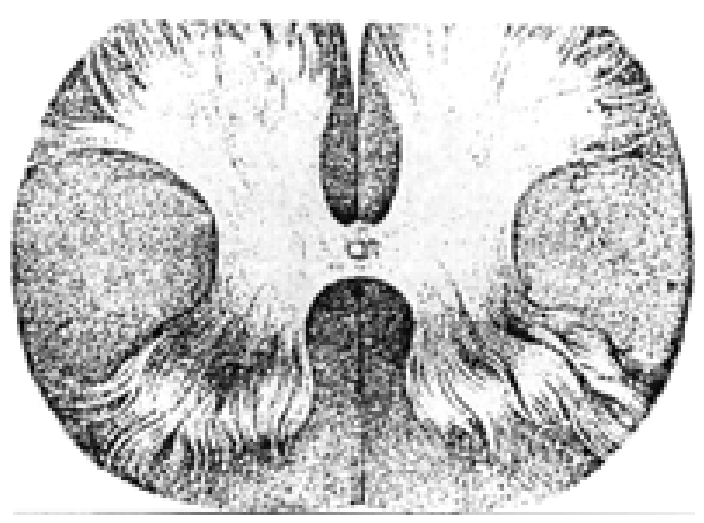

Fig. 6. A section of the spinal cord illustrated by Stilling.

\section{Charles Edouard Brown-Séquard (1817-1894)}

As improvements in histological and experimental techniques became available, modern studies of spinal cord anatomy and function were initiated by Brown-Séquard (Fig. 7 left), a French neurophysiologist. In 1846 he gave the first demonstration of the decussation of sensory tracts. Following a hemisection of the spinal cord, BrownSéquard was able to demonstrate that fibers for touch, pain, and temperature decussate near their level of entry into the spinal cord. He later showed that there was an increase in reflexes ipsilateral to the section in the caudal segments as well as a loss of sensation on the contralateral side. ${ }^{3,4,12,14,17}$

\section{Ludwig Türck (1810-1868)}

The location and direction of fiber tracts were uncovered by experimental studies undertaken by this Austrian neurologist, who described the ventral corticospinal tract of Türck in 1849. In 1853 while working on an injuryrelated degenerated spinal cord, Türck revealed six pathways on each side of the spinal cord: two anterior, two lateral, and two posterior. ${ }^{3,4,12,17}$

\section{Jacob Augustus Lockhart Clarke (1817-1880)}

The English neurologist Clarke is best known for his studies of the spinal cord, in which he identified the nucleus dorsalis that bears his name (Clarke nucleus) in 1851.,3,12,17

\section{Rudolph Albert von Kölliker (1857-1905)}

Von Kölliker (Fig. 7 right), a Swiss anatomist, described the white and gray matter of the spinal cord in greater detail than his predecessors, and examined the intramedullary origin and destination of the motor and sensory roots in 1852. He described the passage of nerve roots through the substantia gelatinosa into the substantia grisea and how some nerve roots turn upward into the posterior column and some disperse in the lateral column. He also noted that some bundles of transverse fibers pass across the commissure to radiate into the opposite posterior horns. ${ }^{34,12,17}$

\section{Paul Emil Flechsig (1847-1929)}

In 1876, Flechsig, a German neuroanatomist, identified and named the dorsal spinocerebellar tract (Flechsig 


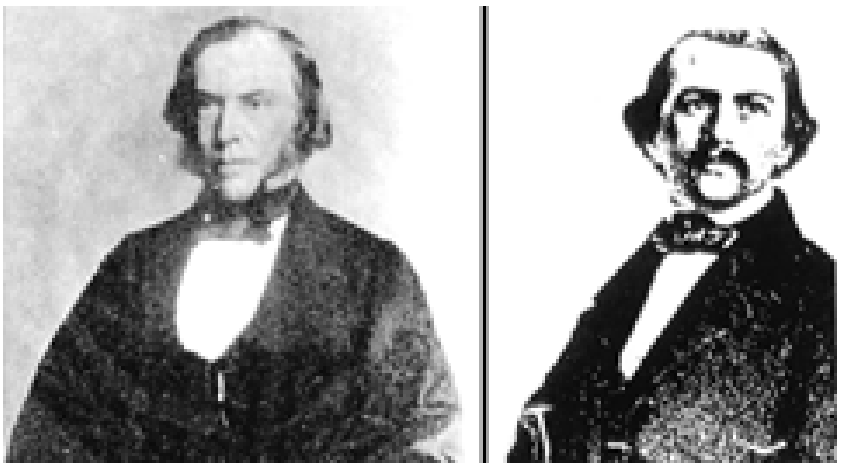

Fig. 7. Left: Photograph showing Brown-Séquard. Right: Portrait of Von Kölliker.

tract). From his work on the pyramidal tract, which he traced from both the pre- and postcentral regions, Flechsig concluded that the corticospinal tract became completely functional only after myelination had been completed. He assumed that fibers subserving a specific function would myelinate at earlier or later times than fibers of other tracts. He stated that approximately 91 to $97 \%$ of the fibers of the pyramidal tracts cross., ${ }^{3,4,12,17}$

\section{William Richard Gowers (1845-1915)}

Gowers (Fig. 8 left), an English neurologist, described the ventral spinocerebellar tract or Gowers tract in $1880 .^{3,4,12,14,17}$

\section{Otfrid Foerster (1873-1941)}

Foerster's work on posterior rhizotomy led to the determination of the dermatomal distribution and borders. ${ }^{3,4,12,23}$

\section{Henry Charlton Bastian (1837-1915)}

In 1890 the English neurologist Bastian demonstrated that, in total transverse lesions of the spinal cord, reflexes below the level of the lesion are lost and muscle tone is abolished. This later became known as the Bastian law., ${ }^{3,12,17}$

\section{Joseph Jules Dejerine (1849-1917)}

Dejerine (Fig. 8 right), a French neurologist, made several clinical contributions to the neurosciences and to our understanding of the spinal cord. He contributed greatly to the study of the following: tabes dorsalis, multiple sclerosis, Charcot disease (amyotrophic lateral sclerosis), combined and primitive sclerosis, transverse myelitis, poliomyelitis, hematomyelia, syringomyelia, spinal cord ataxia, and hereditary progressive interstitial neuritis. Dejerine defined the clinical manifestations of intermittent claudication due to vascular disorders of the spinal cord. Perhaps his most important contribution to spinal cord localization includes the precise description of the somatotopy and connections of the ventral corticospinal tract as well as the lateral and anterior spinothalamic tracts (the "faisceau en croissant" de Dejerine or the crescentlike fasciculus). He theorized about the multiradicular innervation of muscles and about the cell-column deposition of second motor neurons based on his large number of patients with spinal cord injuries and on

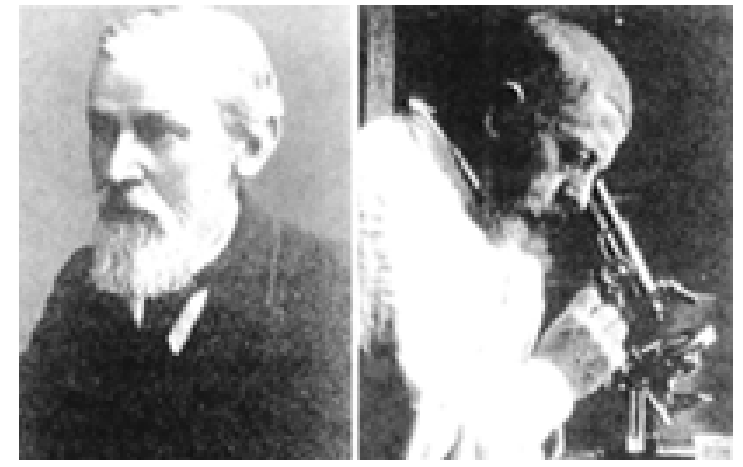

Fig. 8. Left: Photograph of Gowers. Right: Photograph of Dejerine at his microscope.

research studies of monkeys. Dejerine refuted the Bastian law both before and at the beginning of World War I. ${ }^{21}$

\section{Sir Victor Alexander Haden Horsley (1857-1916)}

In 1892 Horsley stated that " $80 \%$ of the afferent impulses travel up the same side of the spinal cord, the $80 \%$ being made up of $60 \%$ of the dorsal going up the posterior column, and $20 \%$ going up the lateral column."

\section{Heinrich Lissauer (1861-1891)}

In 1855 Lissauer, a German neurologist, described the tractus dorsolateralis, which is also known as the tract of Lissauer. $^{12,17}$

\section{Friedrich Goll (1829-1903)}

Goll, a Swiss anatomist, identified the fasciculus gracilis, also known as the tract of Goll, in 1860.,17

\section{Edward Flatau (1869-1932)}

Flatau, a Polish neurologist, observed the laminar nature of spinal pathways in $1894 .{ }^{17}$

\section{Bror Rexed (1914-2002)}

The last important clinical and scientific contribution to our understanding of spinal cord localization is the lamination of the spinal cord. Based on differences in neuronal cytoarchitecture, Bror Rexed, a professor of anatomy at the Institute of Anatomy, University of Uppsala, Sweden, divided the gray matter of the spinal cord into 10 layers (I-X laminae). The neurons in each of these layers are functionally distinct from those of other layers, with each layer having a characteristic pattern of axonal projections.

\section{SUMMARY}

In summary, the eponymic structures in the spinal cord include the substantia gelatinosa of Rolando (1809), the fasciculus cuneatus of Burdach (1826), the ventral corticospinal tract of Türck (1849), the nucleus dorsalis of Clarke (1851), the tract of Lissauer (1855), the fasciculus gracilis of Goll (1860), the dorsal spinocerebellar tract of Flechsig (1876), the ventral spinocerebellar tract of Gowers (1880), and the rubrospinal tract of von Monakow (1910). 
The 20th century ushered in a new era in the evaluation of spinal cord functions and localization; however, a complete understanding of this remarkable organ remains elusive. Perhaps the third millennium will provide the answers to today's questions about spinal cord localization.

\section{References}

1. Bennett MR, Hacker PMS: The motor system in neuroscience: a history and analysis of conceptual developments. Prog Neurobiol $67: 1-52,2002$

2. Breasted JH: The Edwin Smith surgical papyrus, in Wilkins RH (ed): Neurosurgical Classics. Rolling Meadows, IL: AANS, 1992, pp 1-5

3. Clarke E, O'Malley CD: The Human Brain and Spinal Cord: A Historical Study Illustrated by Writings From Antiquity to the Twentieth Century. Berkeley: University of California Press, 1968

4. Finger S: Origins of Neuroscience: A History of Explorations Into Brain Function. New York: Oxford University Press, 1994

5. Hippocrates: The Geniune Works of Hippocrates (translated by Adams F). Baltimore: Williams \& Wilkins, 1939

6. Hippocrates: On nature of bones, in Litre PE (ed): Oeuvres Completes d'Hippocrate. Amsterdam: AM Hakkert, 1982, Vol 9, pp 162-197

7. Hippocrates: On places in man, in Goold GP, Potter P (eds): Hippocrates. The Loeb Classical Library. Cambridge, MA: Harvard University Press, 1995, Vol III, pp 13-101

8. Hippocrates: The sacred disease, in Capps E, Page TE, Rouse WHD (eds): Hippocrates. The Loeb Classical Library. London: W Heinemann, 1923, Vol II, pp 127-183

9. Horsley V: The Stucture and Functions of the Brain and Spinal Cord. London: Griffin, 1892

10. Jackson R: Doctors and Diseases in the Roman Empire, ed 2. London: British Museum Press, 1995

11. Kumar K: Spinal deformity and axial traction. Spine 21: 653-655, 1996
12. Laws ER, Udvarhelyi GB: The Genesis of Neuroscience by A. Earl Walker, M.D. Rolling Meadows, IL: AANS, 1998

13. Loeser JD: History of skeletal traction in the treatment of cervical spine injuries. J Neurosurg 33:54-59, 1970

14. Lyons AS, Petrucelli RJ II: Medicine: An Illustrated History. New York: Abrams, 1978

15. Marketos SG, Skiadas P: Hippocrates: The father of spine surgery. Spine 24:1381-1387, 1999

16. Marketos SG, Skiadas PK: Galen: A pioneer of spine research. Spine 24:2358-2362, 1999

17. McHenry LC Jr: Garrison's History of Neurology. Springfield, IL: CC Thomas, 1969, pp 3-24

18. Naderi S, Acar F, Mertol T, et al: Functional anatomy of the spine by Avicenna in his eleventh century treatise Al-Qanun fi al-Tibb (The Canons of Medicine). Neurosurgery 52: 1449-1454, 2003

19. Plato: Timaeus, in Burry RG (ed): Plato. The London Classical Library. London: W Heinemann, 1929, pp 1-253

20. Sanan A, Rengachary SS: The history of spinal biomechanics. Neurosurgery 39:657-669, 1996

21. Schurch B, Dollfus P: The "Dejerines": an historical review and homage to two pioneers in the field of neurology and their contribution to the understanding of spinal cord pathology. Spinal Cord 36:78-86, 1998

22. Singer CJ: A Short History of Anatomy From the Greeks to Harvey: The Evolution of Anatomy. New York: Dover, 1957

23. Tan TC, Black PM: The contributions of Otfrid Foerster (18731941) to neurology and neurosurgery. Neurosurgery 49: 1231-1236, 2001

24. Von Staden H: Herophilus: The Art of Medicine in Early Alexandria. New York: Cambridge University Press, 1989

Manuscript received November 17, 2003.

Accepted in final form January 5, 2004.

Address reprint requests to: Sait Naderi, M.D., Department of Neurosurgery, Dokuz Eylül University Hospital, Inciralti, 35340, Izmir, Turkey. email: snaderi@deu.edu.tr. 